\title{
PENINGKATKAN KUALITAS MINYAK GORENG CURAH MENGGUNAKAN ADSORBEN LEMPUNG DESA GEMA TERAKTIVASI
}

\author{
Halida Sophia, Akmal Muchtar, Martha Sari
}

\author{
Mahasiswa Bidang Anorganik, Jurusan Kimia \\ Fakultas Matematika dan Ilmu Pengetahuan Alam \\ Kampus Bina Widya Pekanbaru, 28293, Indonesia \\ Adillah_s@yahoo.co.id
}

\section{ABSTRAK}

Telah dilakukan penelitian tentang peningkatan mutu minyak goreng curah menggunakan adsorben lempung asal Desa Gema, Kabupaten Kampar, Provinsi Riau. Penelitian ini meliputi: (1) Pembuatan adsorben dengan aktivasi menggunakan $\mathrm{H}_{2} \mathrm{SO}_{4} 0,5 \mathrm{M}$, selama 3 jam dengan kecepatan pengadukan $500 \mathrm{rpm}$ (2) Pemurnian minyak goreng secara adsorbsi dan mengetahui mutu minyak curah setelah adsorbsi berupa bilangan peroksida, bilangan asam, kandungan air, warna. Proses adsorpsi diamati dengan variasi massa (1, 3, 5, dan 7 gram) dengan waktu kontak 30 menit. Semua nilai yang diperoleh dibandingkan dengan SNI 3741:2013. Hasil yang didapat menunjukkan lempung teraktivasi $\mathrm{H}_{2} \mathrm{SO}_{4}$ mampu menurunkan bilangan peroksida, bilangan asam, dan kandungan air secara maksimal masing-masing sebesar $31,02 \%, 36,36 \%$, dan $38,89 \%$ dengan 7 gram lempung teraktivasi.

Kata kunci: Lempung, adsorpsi, aktivasi, bilangan peroksida, dan bilangan asam

\section{PENDAHULUAN}

Lempung (clay) merupakan salah satu material anorganik yang melimpah di kerak bumi sebagai hasil pelapukan batuan. Provinsi Riau memiliki potensi lempung alam yang cukup besar, seperti yang terdapat di Desa Lipat kain Kabupaten Kampar, Desa Sukamaju Kabupaten Indragiri Hulu, Desa Kulim Kecamatan Bukit Raya, dan Desa Cengar Kabupaten Kuantan Singingi (Muhdarina, 2012)

Lempung banyak diaplikasikan sebagai adsorben, resin penukar ion, katalis dan penyangga katalis, aditif pada sintesis membran, bahan dasar komposit, dan lainnya. Oleh karena itu, usaha dari pengembangan lempung harus terus ditingkatkan agar memperoleh daya guna yang beragam dan menguntungkan.

Aktivasi lempung secara kimia dapat meningkatkan daya adsorbsi lempung. Aktivasi kimia berupa aktivasi menggunakan asam, basa, kation surfaktan, dan polihidroksikation Manohar dkk, 2010). Asam dalam proses aktivasi akan menyebabkan penggantian ion-ion seperti $\mathrm{K}^{+}, \mathrm{Na}^{+}$, dan $\mathrm{Ca}^{2+}$ dalam ruang intemelar, dengan $\mathrm{H}^{+}$dari asam serta akan melepaskan ionion $\mathrm{Al}^{3+}, \mathrm{Fe}^{3+}, \mathrm{Mg}^{2+}$ dari kisi strukturnya sehingga pori-porinya menjadi bersih (Kurniawan, 2008). Keberadaan ion-ion pengotor ini dapat mengurangi efektivitas poripori lempung dalam proses adsorpsi dan pertukaran kation.

Berdasarkan penelitian yang pernah dilakukan oleh Dewi dan Hidajati (2010), yaitu peningkatan kualitas minyak goreng curah menggunakan bentonit teraktivasi sebagai adsorben, maka peneliti tertarik untuk melakukan penelitian untuk memanfaatkan lempung sebagai adsorben dengan mempelajari pengaruh variasi massa dan waktu kontak selama proses adsorpsi.

Bentonit teraktivasi dapat meningkatkan kualitas minyak goreng curah berdasarkan SNI 01-3741-2002. Penggunaan 9 gram bentonit teraktivasi memperoleh hasil yang maksimal. Nilai kecerahan warna (L) 0,8, bilangan asam $0,0630 \%$, bilangan iod 38,1330 . Bentonit yang digunakan diaktivasi dengan $\mathrm{H}_{2} \mathrm{SO}_{4} \quad 1,5 \mathrm{M}$, selama 6 jam telah dilakukan oleh Dewi dan 
Hidajati (2010). Peningkatan kualitas minyak goreng curah ini penting untuk dipelajari mengingat minyak goreng curah merupakan pilihan utama dari masyarakat kalangan ekonomi rendah. Minyak goreng curah memiliki kandungan asam lemak jenuh yang relatif besar sehingga mudah teroksidasi menjadi senyawa yang membahayakan kesehatan, selain itu minyak goreng curah memiliki sanitasi yang rendah karena didistribusikan tanpa kemasan.

\section{METODOLOGI PENELITIAN}

\section{Alat dan Bahan}

Peralatan yang digunakan dalam penelitian ini adalah UV-Vis (UVmini-1240 SHIMADZU, spektrofotometer tipe Spectroquant Pharo 300, SEM (ZEISS)EVO-50, oven (Memmert), hotplate (REXIM RSH-IDR AS ONE), sentrifuge, stirrer, desikator, pengaduk magnet, ayakan 200 mesh, neraca analitis, dan peralatan gelas sesuai prosedur kerja.

Bahan-bahan yang digunakan dalam penelitian ini adalah minyak goreng curah, lempung dari desa Gema Kabupaten Kampar, akuades, $\mathrm{H}_{2} \mathrm{SO}_{4}$ P.A (Merck), $\mathrm{Na}_{2} \mathrm{~S}_{2} \mathrm{O}_{3}$ (Merck), $\mathrm{CH}_{3} \mathrm{COOH}$ P.A (Merck), $\mathrm{CHCl}_{3}$ P.A (Merck), $\mathrm{H}_{2} \mathrm{SO}_{4}$ P.A (Merck), KI, $\mathrm{H}_{2} \mathrm{C}_{2} \mathrm{O}_{4} \cdot 2 \mathrm{H}_{2} \mathrm{O}$, alkohol $96 \%$, larutan pati $1 \%$, dan fenolftalein.

\section{Preparasi dan Aktivasi Adsorben}

Adsorben yang digunakan pada proses adsorpsi adalah lempung asal Desa Gema Kecamatan Kampar kiri, Kabupaten Kampar Propinsi Riau, pada 0,15691 LS dan 101,07885 BT. Sampel dibersihkan dari partikel kasar dengan pencucian menggunakan akuades. Kemudian, dikeringkan dengan suhu $105^{\circ} \mathrm{C}$ selama dua jam. Lempung digiling dan diayak dengan ayakan ukuran 200 mesh. Kemudian disimpan dalam desikator dan dilakukan identifikasi dan karakterisasi untuk mengetahui kristalinitas dan morfologi lempung lempung.

Aktivasi dilakukan secara kimia. Sebanyak $35 \mathrm{~g}$ lempung alam dicampurkan dalam $200 \mathrm{~mL}$ $\mathrm{H}_{2} \mathrm{SO}_{4} \quad 0,5 \quad \mathrm{M}$. Campuran tersebut diaduk menggunakan pengaduk magnet dengan kecepatan pengadukan $500 \mathrm{rpm}$ pada suhu $45^{\circ} \mathrm{C}$ selama 3 jam. Setelah proses pemanasan lempung dicuci dengan akuades sampai $\mathrm{pH}$ netral, dan dikeringkan pada suhu $105^{\circ} \mathrm{C}$ kemudian, diayak kembali untuk memperoleh keseragaman ukuran. Lempung 200 mesh ini digunakan untuk penjernihan minyak goreng curah.

\section{Penentuan Karakter Minyak Goreng Curah}

Peningkatan kualitas minyak goreng curah dipelajari beberapa karakter diantaranya bilangan peroksida, bilangan asam dan kandungan air.

Variabel yang diteliti adalah variasi konsentrasi dan waktu kontak. Sebanyak 250 gram minyak goreng dipanaskan hingga temperatur $105^{\circ} \mathrm{C}$. ketika minyak mencapai temperatur $\quad 70^{\circ} \mathrm{C}$ ditambahkan lempung teraktivasi dengan dengan variasi massa $(1,3,5$, dan 7 gram). Kemudian, larutan diaduk menggunakan pengaduk magnet dengan kecepatan $500 \mathrm{rpm}$ selama 30 menit. Minyak goreng curah hasil adsorpsi ini.

\section{HASIL DAN PEMBAHASAN Karakterisasi Lempung Setelah Perlakuan}

Hasil analisis dengan FTIR seperti yang ditunjukkan pada Gambar 2. (a) dan (b), lempung alam memperlihatkan adanya pita lebar pada bilangan gelombang 3620,54 $\mathrm{cm}^{-1}$ diberikan untuk vibrasi ulur gugus hidroksil $\mathrm{Mg}-\mathrm{OH}, \mathrm{Al}-\mathrm{OH}$ atau $\mathrm{Fe}-\mathrm{OH}$, khas untuk monmorilonit (Moraes dkk., 2011). Pelebaran pita disebabkan banyaknya molekul air yang terkandung dalam kerangka monmorilonit didukung dengan sifat swellability dari monmorilonit. Pita serapan pada bilangan gelombang $1001,10 \quad \mathrm{~cm}^{-1}$ mengindikasikan vibrasi ulur Si-O dari Si-O-Si. Pita serapan pada bilangan gelombang 936,48 $\mathrm{cm}^{-1}$ menunjukkan adanya vibrasi tekuk $\mathrm{Al}-\mathrm{OH}$ pada lapisan oktahedral. 914,30 $\mathrm{cm}^{-1}$ merupakan daerah bilangan gelombang untuk puncak aluminosilikat (Al-O) (Dewi dan Hidajati, 2010). Sedangkan pada lempung teraktivasi menunjukkan perbedaan pada puncak 3588,72 $\mathrm{cm}^{-1}$ terdapat pada lempung alam tetapi tidak terdapat pada lempung teraktivasi, hal ini dikarenakan terjadi pelepasan pengotor-pengotor 
dari kisi-kisi struktur, sehingga secara fisiknya lempung tersebut menjadi aktif.

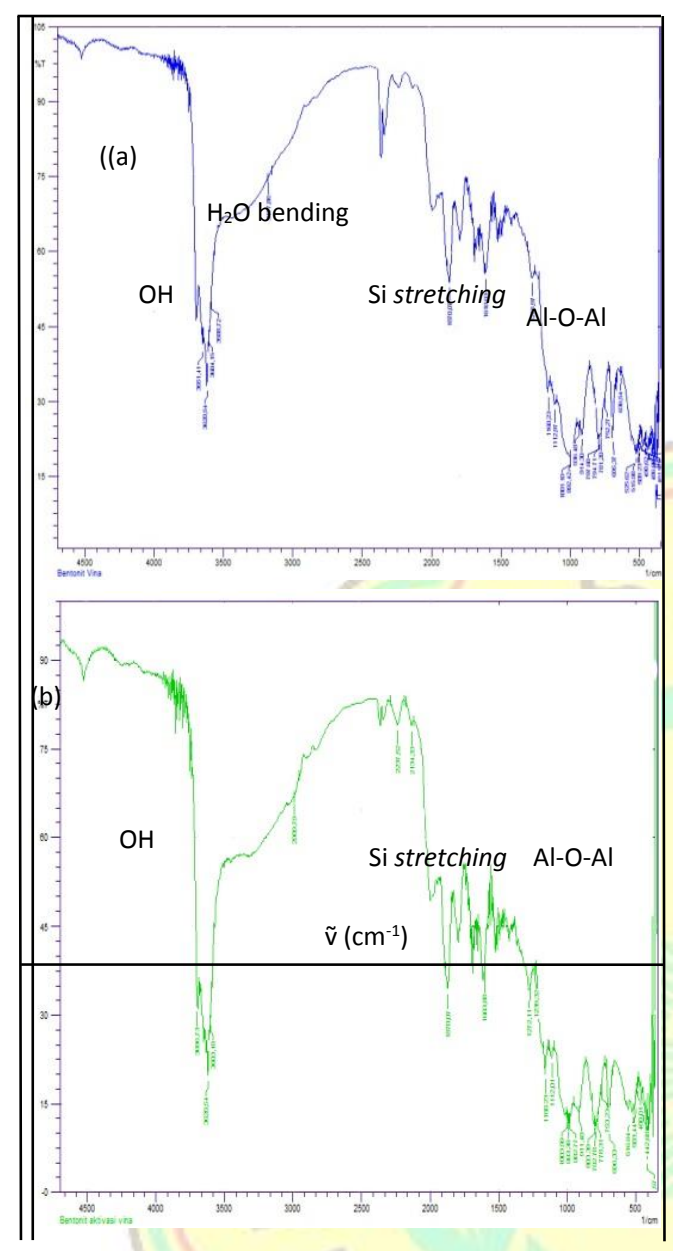

Gambar 1. (a) Gugus fungsi lempung tidak teraktivasi (b) Gugus fungsi lempung teraktivasi $\mathrm{H}_{2} \mathrm{SO}_{4} 0,5 \mathrm{M}$.

\section{Uji Kualitas Minyak Goreng Curah setelah Proses Adsorbsi}

Bilangan peroksida adalah banyaknya miliekivalen oksigen aktif yang terdapat dalam 1000 gram minyak atau lemak. Syarat mutu bilangan peroksida pada minyak goreng menurut SNI 3741:2013 maksimal sebesar 10 mek $\mathrm{O}_{2} / \mathrm{g}$ minyak.

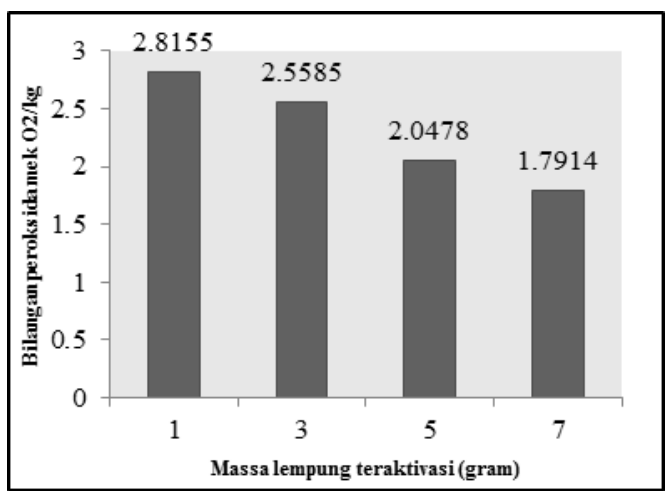

Gambar 2. Pengaruh variasi massa adsorben terhadap bilangan peroksida minyak curah (bilangan peroksida sebelum adsorpsi 2,9680\%)

Gambar 2, menunjukkan terjadinya penurunan bilangan peroksida yang untuk setiap penambahan massa lempung teraktivasi. Kemampuan lempung teraktivasi untuk mengurangi angka peroksida dalam minyak disebabkan oleh adanya gugus silanol (Si-O-H). Lempung memberikan daya adsorpsi yang cukup besar karena pada lempung oksigen penghubung antar dua lapisan silika yang mengapit satu lapisan alumina terikat sangat lemah, ini menyebabkan strukturnya mudah mengembang sehingga peroksida dan molekul air mudah bergerak diantara unit kristal. Peroksida dapat masuk ke dalam struktur dan menggantikan ion hidrogen yang lepas untuk menetralkan muatannya.

Adanya asam lemak bebas dalam minyak tidak dikehendaki terutama adanya asam lemak dengan rantai karbon pendek, karena adanya asam lemak bebas tersebut akan memberikan rasa yang tidak disukai pada minyak serta dapat menurunkan stabilitas minyak saat disimpan. Perlakuan dengan adsorben diharapkan dapat menurunkan kandungan asam lemak bebas dalam minyak. Kandungan asam lemak bebas dalam minyak dapat dinyatakan sebagai angka asam yang setara dengan banyaknya $\mathrm{KOH}$ yang diperlukan untuk menetralkan asam lemak bebas yang ada dalam 1 gram minyak. Pada penelitian ini untuk menetralkan asam digunakan $\mathrm{NaOH}$. 


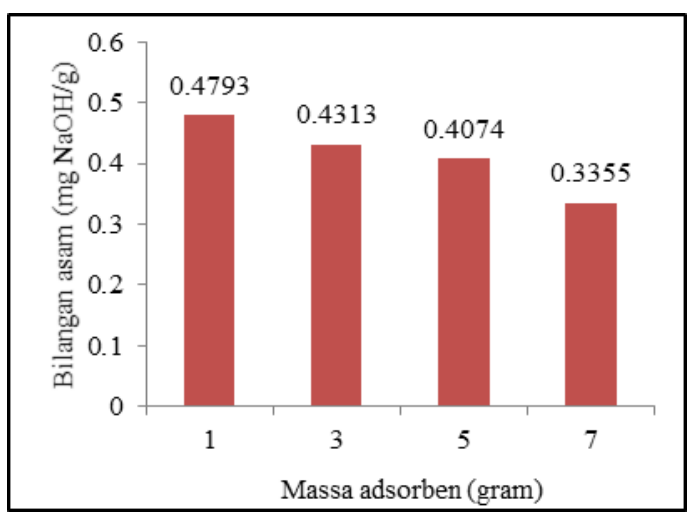

Gambar 5. Pengaruh variasi waktu kontak terhadap bilangan asam minyak goreng curah (bilangan asam sebelum adsorpsi 0,5272\%).

Lempung teraktivasi berpotensi dalam menurunkan bilangan asam pada minyak goreng. Penentuan bilangan asam dilakukan dengan menggunakan titrasi asam basa. Reaksi yang terjadi merupakan reaksi yang menghasilkan garam.

$$
\mathrm{RCOOH}+\mathrm{NaOH} \longrightarrow \mathrm{RCOOK}+\mathrm{H}_{2} \mathrm{O}
$$

Minyak goreng curah segar (kontrol) memiliki bilangan asam 0,5272 $\mathrm{mgNaOH} / \mathrm{g}$. Nilai ini masih di dalam kisaran SNI 3714:2013, nilai bilangan asam yang diizinkan adalah maksimal 0,6 mg KOH/g. Setelah proses adsorpsi, penambahan massa adsorben memberikan hasil yang linear terhadap penurunan bilangan asam pada minyak goreng curah. Semakin banyak massa adsorben yang digunakan semakin rendah bilangan asam yang diperoleh. Bilangan asam paling rendah diperoleh pada penambahan 7 gram lempung teraktivasi yaitu $0,3355 \mathrm{mg} \mathrm{NaOH} / \mathrm{g}$.

Berdasarkan SNI 3741:2013 standar minyak goreng yang layak, mengandung kandungan air maksimum $0,15 \%$. Air adalah konstituen yang keberadaannya dalam minyak sangat tidak diinginkan karena dapat menghidrolisis minyak menghasilkan asam asam lemak bebas yang menyebabkan bau tengik pada minyak (Poedjiadi, 1999).

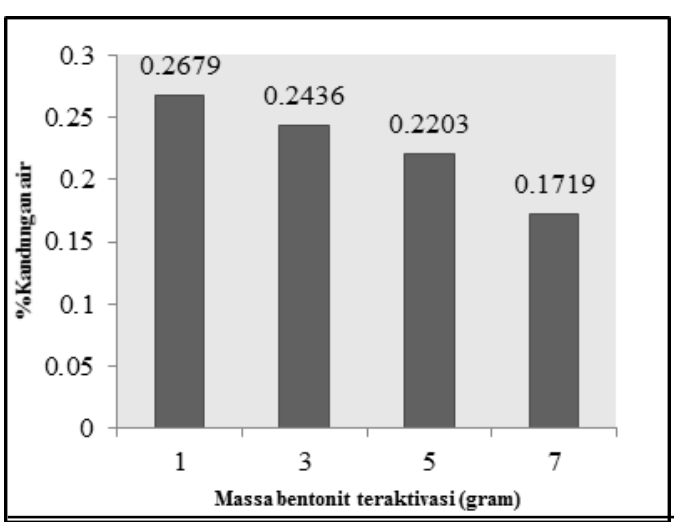

Gambar 6. Pengaruh variasi massa lempung teraktivasi terhadap kandungan air minyak goreng (kandungan air sebelum adsorpsi 0,2796 $\%)$

Kandungan air pada minyak goreng curah awal memiliki nilai diluar standar SNI 3741:2013. Adsorpi dengan 7 gram lempung teraktivasi menunjukkan penurunan hingga 0,1719 (Gambar 19). Nilai ini belum optimum menunjukk pengurangan molekul air di dalam minyak goreng curah. Namun, tetap belum memenuhi SNI.

\section{KESIMPULAN}

Hasil yang didapat menunjukkan lempung teraktivasi $\mathrm{H}_{2} \mathrm{SO}_{4}$ mampu menurunkan bilangan peroksida, bilangan asam, dan kandungan air secara maksimal, masing-masing adalah $31,02 \%, 36,36 \%$ dan $38,89 \%$, dengan 7 gram lempung teraktivasi. Nilai kandungan air hasil adsorpsi belum memenuhi SNI 3741:2013.

\section{DAFTAR PUSTAKA}

Dewi, M dan Hidajati, N. 2012. Peningkatan mutu minyak goreng curah menggunakan adsorben bentonit teraktivasi. UNESA Journal of chemistry. 1: No. 2.

Kurniawan, D. 2008. Modifikasi Bentonit menjadi Organoclay dengan Metode Ultrasonik Sebagai Absorven $P$ Klorofenol dan Hidroquinon. Skripsi Jurusan Kimia Fakultas Matematika dan Ilmu Pengetahuan Alam. Universitas Indonesia, Jakarta.

Manohar, D. M., Noeline, B. F. and Anirudhan, T. S. 2006. Adsorption Performance of Al-pillared Bentonite Clay for The 
Removal of Cobalt(II) from Aqueous Phase. Applied Clay Science. 31:194-206.

Muhdarina. 2012. Melirik Potensi Lempung Alam di Wilayah Riau, dalam Minda Emas Dosen Perempuan (Sempena 50 tahun Universitas Riau). Ningsih, R.B (Editor). UR Press. Pekanbaru. ISBN 978979-792-333-4.

Poedjiadi, A. 1999. Dasar-Dasar Biokimia. UIPress, Jakarta.

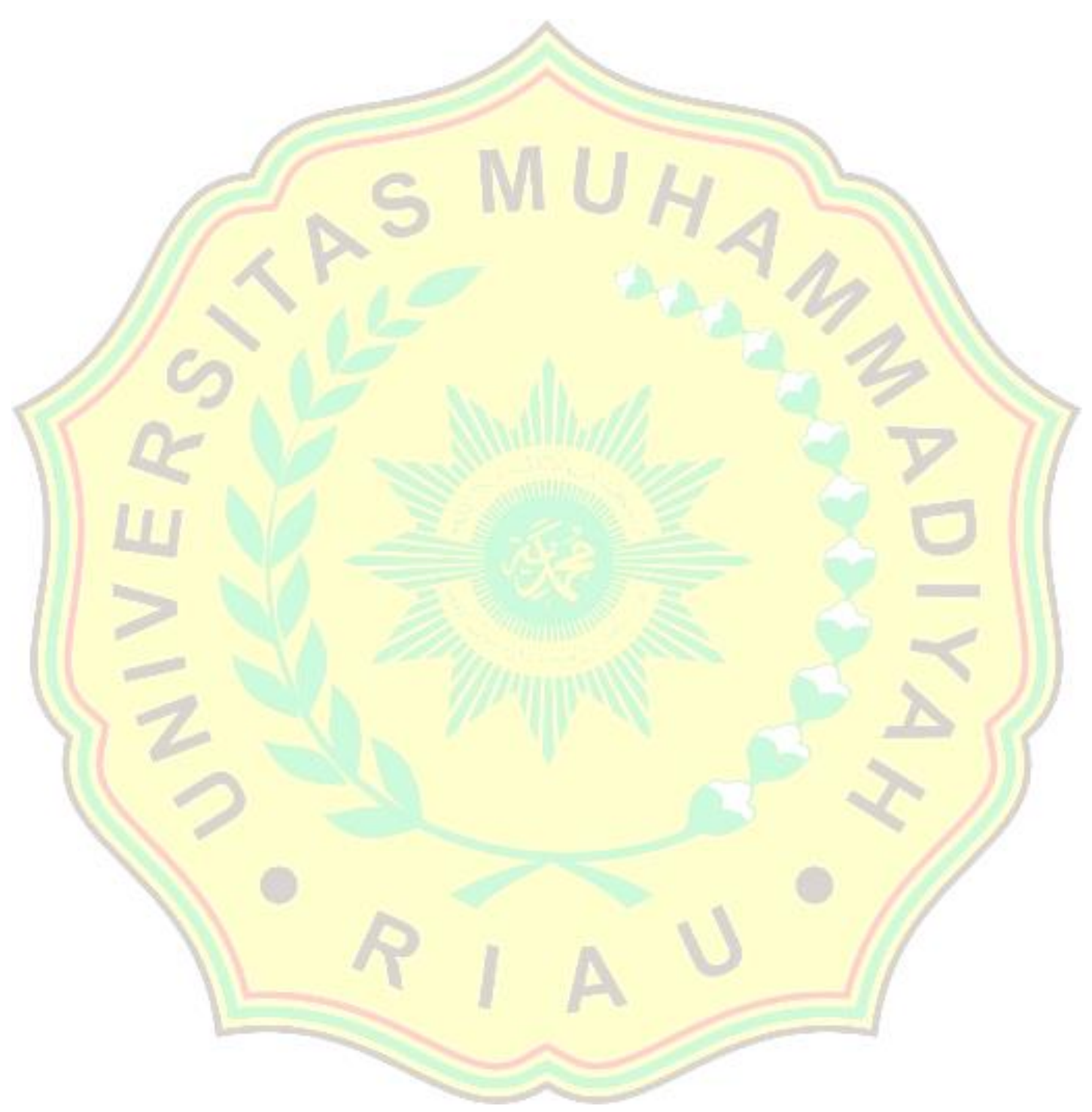

